\title{
Trichodinid Parasites on the Gills of Channa punctatus from the Wild and Cultured Environments in Sylhet, Bangladesh
}

\author{
Mitu Deb, Md. Faruque Miah, Mohibur Rahman, and Zobada Kanak Khan \\ Department of Genetic Engineering and Biotechnology, Shahjalal University of Science and Technology, Sylhet 3114, Bangladesh \\ Correspondence should be addressed to Md. Faruque Miah; faruque-btc@sust.edu
}

Received 28 September 2014; Revised 10 January 2015; Accepted 11 January 2015

Academic Editor: Cleber Galvão

Copyright (C) 2015 Mitu Deb et al. This is an open access article distributed under the Creative Commons Attribution License, which permits unrestricted use, distribution, and reproduction in any medium, provided the original work is properly cited.

\begin{abstract}
Two trichodinid parasites, Trichodina cyprinocola and Trichodina pediculus, were acknowledged in the gills during a sampling preparation of thirty fish Channa punctatus from the wild and cultured environments. However, Trichodina pediculus was recorded only in one farmed fish. From a total of 33 parasites, $26.67 \%$ were encountered in wild and $46.67 \%$ in cultured fish. The overall incidence of infection by Trichodina cyprinocola was 33.33\% whilst Trichodina pediculus was only 3.33\%. Records from statistical analysis as well affirmed that fish host from the cultured environment constituted the highest rate of intensity (3.43 \pm 1.4$)$, density $(1.6 \pm 2.0)$, and infection index $(11.2 \pm 13.95)$ values. Both trichodinid species are identified based on the study in their unique denticles structure. Relatively large size of adhesive disc with tiny curved denticles and elongated denticle rays are the exceptional denticle morphology observed in Trichodina pediculus and compact association of sickle denticles with round tangent point alongside short vigorous upright rays evaluated the Trichodina cyprinocola.
\end{abstract}

\section{Introduction}

Snake headed fish are abundantly found in all the freshwater habitats of Bangladesh and they are less catch in river or running water but good catch in flood plains. Five snake headed fish such as Channa punctatus, C. striatus, C. marulius, C. barca, and C. orientalis are known in Bangladesh but they are becoming scarce during the recent years. Channa punctatus is one of the popular snake headed fish in Bangladesh with highly developed parental care. It has good commercial value due to its diversified diet menu. Channa punctatus is the most popular fish species in Sylhet but their abundance is reducing due to overexploitation, environmental stress, and disease outbreaks [1]. Most parasitic diseases occur due to unfavorable conditions, such as poor water quality. Previous studies on Channa punctatus have been done in biological field, mainly in the breeding program of this fish [2], and in histopathology of diseased fish $[3,4]$. Helminth parasites in C. striatus and C. marulius are listed [5] and some other researches were done on the snake headed fishes with different parasites [6-8].

Protozoan parasites such as Ichthyobodo, Chilodonella, Ichthyophthirius, and Trichodina are most common in fish species [9-12]. Study of protozoan parasites is scant in
Bangladesh, and a little knowledge about the distribution, prevalence, parasitic intensity, pathogenic effects, and control of most of the diseases in natural population of freshwater fish is studied in Sylhet region. Trichodinids are one of the important ectoparasite protozoa that are typically found on the gills, skin, and fins of fishes described as chalice shaped with homocentric layers of cilia and a circle of coordinating cytoskeletal denticles [13-15]. About 300 nominal Trichodina species have been reported from different environments [16-19], but their geographic distribution and diversity in Bangladesh, particularly in Sylhet region, are still largely unknown. Due to high economic importance of $C$. punctatus in Bangladesh the present work was undertaken to investigate the trichodinid parasites in C. punctatus with different habitat of varying water quality in Sylhet. The major objectives of the present study were to observe the trichodinid parasites on the gills of $C$. punctatus from the wild and cultured ecosystems and to find out the prevalence and mean intensity of infestation of trichodinid parasites in Channa punctatus.

\section{Materials and Methods}

2.1. Study Location and Fish Sampling. Thirty young fish $C$. punctatus were sampled in live condition from wild and 
cultured environments where 15 individuals were selected for each environment for observing trichodinid parasites on gills. Open water fish were collected in live condition from local fish market and closed water fish were harvested by fishing net from different cultured farms of Sylhet. Single fish was collected and examined in daily basis. Collected fish was transferred to the Animal Biotechnology Laboratory (ABL) of the Department of Genetic Engineering and Biotechnology (GEB) at Shahjalal University of Science and Technology (SUST), Sylhet, Bangladesh, and C. punctatus was identified according to the morphometric characteristics [20].

2.2. Working Procedure. The gills of collected fish were examined immediately for trichodinid study. A fine pair of scissors was used to cut operculums from both sides to reveal the opercular cavity. Firstly, a clean spatula was drawn to lift off the slime from both sides of gills of each individual and spread on a clean dry glass slide evenly to air-dry and the slime sample was observed under microscope. Then, the whole gill filaments were dissected using fine scissors and impression smears of gills were prepared. Later, three to four drops of the preparation were placed onto clean glass slides and left to dry. Soon after, the air-dried slides with trichodinid parasites were impregnated with a $2 \%$ solution of silver nitrate for 6 to 8 minutes known as Klein's dry silver impregnation technique [21]. Finally, the prepared slides were settled under the compound microscope and visualized by $4 \mathrm{x}, 10 \mathrm{x}$, and $40 \mathrm{x}$ lenses for comprehensive morphological details of the trichodinid parasites [22-26]. The numbers of observed parasites were counted for statistical analysis and microscopic photographs were made for identification of trichodinid species with the help of high megapixel digital camera (Hitachi HDC-1296E).

2.3. Statistical Measurements. To persuade the incidence, intensity, density, and index of this study following subsequent formulae were undertaken to fulfill the analysis [27]:

$$
\begin{aligned}
& \text { Incidence of infection }=\frac{\text { Infected host } \times 100}{\text { Total host examined }}, \\
& \text { Intensity of infection } \\
& =\frac{\text { No. of parasites collected in a sample }}{\text { No. of infected host }}, \\
& \text { Density of infection } \\
& =\frac{\text { No. of parasites collected in a sample }}{\text { Total host examined }}
\end{aligned}
$$

Index of infection

$$
=\frac{\text { No. of host infected } \times \text { No. of parasites collected }}{\text { Total host examined }} \text {. }
$$

\section{Results}

3.1. Identification of Trichodina Species. Two trichodinid species, Trichodina pediculus [28] and Trichodina cyprinocola

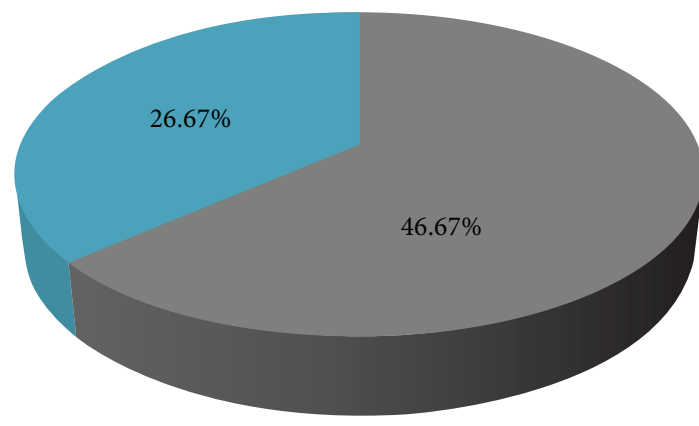

Cultured

Wild

FIGURE 1: Incidence of trichodinid parasites in Channa punctatus.

[26], were identified in this study. Trichodina cyprinocola was noticed in both cultured and wild host while T. pediculus was found only in cultured fish. This is the first record of $T$. cyprinocola in C. punctatus in Bangladesh. Both trichodinid species are identified based on the study in their unique denticles structure.

3.2. Parasitic Status of Fish. In this study, a total of 33 trichodinid parasites were found including 32 of the species T. cyprinocola and only one were found $T$. pediculus. Only one individual of the species T. pediculus was observed in cultured fish and this species was not observed in experimental wild fish. Nine individuals of parasite T. cyprinocola were recorded from wild fish and 23 individuals were found from cultured fish (Table 1).

3.3. Trichodinid Infestation. The analysis of incidence, intensity, density, and parasitic index of two trichodinid gill parasites was carried out from the fish, C. punctatus (Tables 1 and 2). The overall incidence of infection of two trichodinid parasite species in C. punctatus was found higher $46.67 \%$ in fish from cultured environment where in wild environment it was recorded relatively low as 26.67\% (Figure 1). Consequently, cultured environment fish as well pointed out maximum values for intensity $(3.43 \pm 1.4)$, density $(1.6 \pm 2.0)$, and index $(11.2 \pm 13.95)$ whilst minimum statistics $(2.25 \pm$ $0.5,0.6 \pm 1.06$, and $2.4 \pm 4.22$, resp.) were directed to wild environment fish (Table 2).

\section{Discussion}

Several studies on fish parasites have been done in Sylhet but there is not any specific research in C. punctatus. Therefore, this is the first specific account of trichodinid parasites on the gills of C. punctatus in Sylhet and two trichodinid parasites T. cyprinocola and T. pediculus were found. Trichodinid parasite, T. pediculus, was also recorded from the gills of the major carp, Cirrhinus mrigala (Hamilton) in Bangladesh [29]. Other trichodinids, such as T. cirratus, T. colisee, T. 
TABLE 1: Trichodinid parasites of Channa punctatus.

\begin{tabular}{lccccc}
\hline \multirow{2}{*}{ Trichodinid species } & \multicolumn{2}{c}{ Number of observed parasites } & \multirow{2}{*}{ Total infected host } & Total parasites counted & Incidence of infection (\%) \\
& Wild fish & Cultured fish & 1 & 1 & 3.33 \\
Trichodina pediculus & 0 & 1 & 10 & 32 & 33.33 \\
Trichodina cyprinocola & 9 & 23 & 1 & \multirow{2}{*}{. } \\
\hline
\end{tabular}

TABle 2: Intensity, density, and index of Trichodina species in Channa punctatus.

\begin{tabular}{lcccccc}
\hline Environments & Host examined & Infected host & Parasites found & Intensity & Density & Index \\
\hline Wild & 15 & 4 & 9 & $2.25 \pm 0.5$ & $0.6 \pm 1.06$ & $2.4 \pm 4.22$ \\
Cultured & 15 & 7 & 24 & $3.43 \pm 1.4$ & $1.6 \pm 2.0$ & $11.2 \pm 13.95$ \\
\hline
\end{tabular}

glossogobius, T. oreochromis, and T. sylhetensis were reported from some Bangladeshi fish but not in C. punctatus [30, 31].

In the present parasitic surveillance, the highest incidence of infection by trichodinids in C. punctatus was calculated as $46.67 \%$ in the cultured fish whereas in the wild fish the infestation was found to be lowest (26.67\%). A comparative study of the common protozoan parasites encountered on the gills of the wild Clarias gariepinus constituted the highest parasite load (40.54\%) compared to the fish sampled from the cultured environment (38.86\%) [32]. Abo-Esa investigated the ectoparasitic protozoan in Clarias gariepinus and revealed an average infection of $20 \%$ with Trichodina sp. [33]. The recorded data for intensity of infection by trichodinid parasites in wild and cultured fish were $2.25 \pm 0.5$ and $3.43 \pm 1.4$, respectively. Additionally, high level of density $(1.6 \pm 2.0)$ and index $(11.2 \pm 13.95)$ rate by trichodinid parasites was observed in the cultured fish. From the site sampling comparison it was strongly supported that the parasitic infestation is a leading event of the cultural environment fish, which is in agreement with the findings of Miah et al. [34].

Trichodina pediculus, firstly reported by Ehrenberg [28], is a widely distributed species occurring not only in Hydra, but also in tadpoles and various species of fish [28, 35-37]. Regarding the overall morphology of the adhesive disc, $T$. cyprinocola was similar to two known species, T. gulshae [38] and T. heterodentata $[38,39]$. T. cyprinocola possesses close body size and sickle-shaped blade similar to T. gulshae. Several unique characteristics of T. cyprinocola are distinguishable from T. gulshae. Firstly, with respect to the denticle morphology, in T. cyprinocola, apophysis of blade is present but not distinct, blade connection is strong, and ray is very robust, short, and not inclining forward or backward whereas, in $T$. gulshae, apophysis of blade is more prominent, blade connection is relatively thinner, and the ray is much more slender and slanted in anterior direction. Subsequently, T. cyprinocola is a parasite from the cultured cyprinid fish C. carpio, whereas T. gulshae was isolated from the siluriform fish Mystus cavasius. In the present study, relatively large size of adhesive disc with tiny curved denticles and elongated denticle rays are the exceptional denticle morphology observed in $T$. pediculus. Evenly, compact association of sickle denticles with round tangent point alongside short vigorous upright rays evaluated the T. cyprinocola. On the basis of overall denticles shape, the present species resembles more closely $T$. heterodentata [39]. Though, T. cyprinocola was also different from T. heterodentata in several aspects, as the adhesive disc of $T$. heterodentata was significantly larger than that of $T$. cyprinocola with a greater number of radial pins per denticle. With reference to the morphology of denticles, T. cyprinocola possesses much broader sickle-blades with sharp tangent point; its distal blade surface is significantly higher than the round tangent point, unlike that of $T$. heterodentata.

\section{Conclusions}

Channa punctatus was mostly infected by different parasites whereas protozoan is the most common parasite which infects the gills. Not being exception, two species of protozoan trichodinid were found in this observation. These parasites were not listed in any previous parasitic studies of C. punctatus in Bangladesh.

\section{Conflict of Interests}

The authors declare that there is no conflict of interests regarding the publication of this paper.

\section{References}

[1] M. G. Hussain, "Freshwater fishes of bangladesh: fisheries, biodiversity and habitat," Aquatic Ecosystem Health and Management, vol. 13, no. 1, pp. 85-93, 2010.

[2] S. J. Srivastava and R. Singh, "Seasonal changes in the testes of a freshwater murrel, Channa punctatus," Naturalia, vol. 19, pp. 119-130, 1994.

[3] K. J. Chandra, "The anatomy and histology of the alimentary tract of perch, Perca fluviatilis (L.)," Progressive Agriculture, vol. 9, pp. 157-162, 1998.

[4] T. Afroz, M. R. Nabi, and G. Mustafa, "The morphohistology of alimentary canal of Chapila, Gudusia chapra," Bangladesh Journal of Zoology, vol. 27, pp. 51-55, 1999.

[5] A. K. M. Bashirullah, "A brief survey of the helminth fauna of certain marine and freshwater fishes of Bangladesh," Bangladesh Journal of Zoology, vol. 1, pp. 63-81, 1973.

[6] A. K. Chowdhury, Helminth parasite infestation of histopathological changes in snake-head fishes [M.S. thesis], Department of Zoology, University of Dhaka, Dhaka, Bangladesh, 1992.

[7] S. Nahar, H. Khanum, and Z. Zaman, "Comparative study of parasites of Channa striatus [sic] and Channa marulius in Bangladesh," in Aquatic Animal Health and the Environment. 
Second Symposium on Diseases in Asian Aquaculture, p. 96, Scientific Sessions Abstracts, Fish Health Section, Asian Fisheries Society, Karon Villa Phuket Hotel, Phuket, Thailand, 1993.

[8] M. J. Alam, M. Rakibuzzaman, and M. M. Hasan, "Comparative study of endo-parasite infestation in Channa punctatus collected from Hatchery Sewage lagoon," Nature and Science, vol. 8, no. 5, pp. 152-156, 2010.

[9] M. A. Hossain and G. Barua, "Diseases of cultured fish and their control," in Improved Fish Culture Management Practices, M. V. Gupta, Ed., pp. 175-191, Fisheries Research Institute, Mymensingh, Bangladesh, 1991.

[10] M. A. Hossain and M. H. Khan, "Prevalence of ectoparasites of carps in Bangladesh nurseries," in Proceedings of the 3rd Asian Fisheries Forum, Singapore Abstracts, p. 51, Asian Fisheries Society, 1992.

[11] M. B. R. Chowdhury, "Research priorities for microbial fish and its control in Bangladesh," in Research Priorities in Bangladesh for Fish Health, Disease Prevention and Pathology, A. Tollervey, Ed., pp. 8-11, BAU, Dhaka, Bangladesh, 1993.

[12] A. N. H. Banu, M. H. Khan, M. A. Hossain, and M. E. Azim, "Parasitic diseases of freshwater fish," in Nursery Operation System of Bangladesh, Abstract. No 61, Fourth Symposium on Diseases in Asian Aquaculture, Aquatic Animal Health for Sustainability, Cebu International Convocation Centre, Cebu City, Philippines. Asian Fisheries Society, 1999.

[13] L. Basson, J. G. van As, and I. Paperna, "Trichodinid ectoparasites of cichlid and cyprinid fishes in South Africa and Israel," Systematic Parasitology, vol. 5, no. 4, pp. 245-257, 1983.

[14] L. Basson and J. G. van As, “Trichodinid (Ciliophora; Peritricha) gill parasites of freshwater fish in South Africa," Systematic Parasitology, vol. 9, no. 2, pp. 143-151, 1987.

[15] J. G. van As and L. Basson, "A further contribution to the taxonomy of the Trichodinidae (Ciliophora: Peritrichia) and a review of the taxonomic status of some fish ectoparasitic trichodinids," Systematic Parasitology, vol. 14, no. 3, pp. 157-179, 1989.

[16] J. Lom and I. Dykova, Protozoan Parasites of Fishes, vol. 26 of Developments in Aquaculture and Fisheries, 1992.

[17] W. B. Song, Y. J. Zhao, and K. D. Xu, Eds., Pathogenic Protozoa in Mariculture, Science Press, Beijing, China, 2003, (Chinese).

[18] F. H. Tang and Y. J. Zhao, “Taxonomic study on three species of Trichodina Ehrenberg, 1838 with pathologic research on gill tissue of Carassius auratus caused by Trichodina heterodentata Duncan, 1977: a study on trichodinids from freshwater fishes in Chongqing II," Journal of Chongqing Normal University, vol. 4, pp. 8-15, 2007.

[19] F. H. Tang and Y. J. Zhao, “Taxonomic study on trichodinids parasitic on gills of freshwater fish, Carassius auratus from Chongqing, china, with the description of Trichodina brevicirra sp. nov," Acta Hydrobiologica Sinica, vol. 34, no. 5, pp. 1004-1011, 2010.

[20] M. Shafi and M. A. A. Quddus, Bangladesher Matshya Sampad, Bangla Academy, Dhaka, Bangladesh, 1982, (Bengali).

[21] B. M. Klein, "The 'dry' silver method and its proper use," The Journal of Protozoology, vol. 5, no. 2, pp. 99-103, 1958.

[22] T. D. Soota, "Studies on nematode parasites of Indian vertebrates I. Fishes," Records of the Zoological Survey of India Occasional Paper 54, 1983.

[23] R. M. Cable, An Illustrated Laboratory Manual of Parasitology, Burgess Publishing Company, Minneapolis, Minn, USA, 1958.
[24] Z. Kabata, Parasites and Diseases of Fish Cultured in the Tropics, Taylor \& Francis, 1985.

[25] K. J. Chandra, A Practical Text Book of Fish Parasitology and Health Management, The Bangladesh University Grants Commission, Dhaka, Bangladesh, 2008.

[26] F. Tang and F. Zhao, "Study of trichodinids (Protozoa, Ciliophora) parasitic on gills of freshwater fishes from Chongqing, China, and identification of a new species Trichodina cyprinocola sp. nov," African Journal of Microbiology Research, vol. 5, no. 26, pp. 5523-5527, 2011.

[27] L. Margolis, G. W. Esch, and J. C. Holmes, “The use of ecological terms in parasitology (report of an ad hoc committee of the American society of parasitologists)," Journal of Parasitology, vol. 68, no. 1, pp. 131-133, 1982.

[28] C. G. Ehrenberg, Der Infusionsthierchen als Vollkommene Organismen, Verlag von Leopold Voss, Leipzig, Germany, 1838.

[29] A. S. Bhuiyan, S. Akther, and N. E. Amena, "Seasonal occurrence of parasites of the major carp, Cirrhina mrigala (Hamilton) collected from Rajshahi, Bangladesh," University Journal of Zoology, Rajshahi University, vol. 29, pp. 47-50, 2010.

[30] G. S. M. Asmat and N. Sultana, "Four new species of Trichodina Ehrenberg, 1830 (Ciliophora: Trichodinidae) from Bangladeshi fish," Pakistan Journal of Biological Sciences, vol. 8, no. 6, pp. 895-900, 2005.

[31] G. S. M. Asmat, A. K. M. Hafizuddin, and M. M. A. Habib, “Trichodina sylhetensis sp. n. (Ciliophora: Trichodinidae) from the Mud Perch, Nandus nandus (Hamilton-Buchanan, 1822) (Nandidae) in Sylhet," Pakistan Journal of Biological Sciences, vol. 6, no. 20, pp. 1774-1777, 2003.

[32] S. Omeji, S. G. Solomon, and E. S. Idoga, "A comparative study of the common protozoan parasites of Clarias gariepinus from the wild and cultured environments in Benue State, Nigeria," Journal of Parasitology Research, vol. 2011, Article ID 916489, 8 pages, 2011.

[33] J. F. K. Abo-Esa, "Study on some ectoparasitic diseases of catfish, Clarias gariepinus with their control by ginger, Zingiber officiale," Mediterranean Aquaculture Journal, vol. 1, no. 1, pp. 19, 2008.

[34] M. F. Miah, M. Deb, H. Ali, M. M. A. Quddus, and K. Ahmed, "Comparative surveillance of parasitic infestation in Channa punctatus (Osteichthys: Channidae) collected from open and closed water in Sylhet, Bangladesh," Advances in Zoology and Botany, vol. 1, no. 1, pp. 17-23, 2013.

[35] S. L. Kazubski, "Morphological variation of the ciliate Trichodina pediculus Ehrenberg, 1838. I. Parasitising hydras," Acta Protozoologica, vol. 30, pp. 169-175, 1991.

[36] S. L. Kazubski, "Morphological variation of the ciliate Trichodina pediculus Ehrenberg, 1838. II. Parasitising on tadpoles," Acta Protozoologica, vol. 30, pp. 177-186, 1991.

[37] S. L. Kazubski, "Morphological variation of the ciliate Trichodina pediculus Ehrenberg, 1838. III. 190 parasitising on crucian carp (Carassius carassius (L.)) from small ponds in Kortowo (Olsztyn)," Acta Protozoologica, vol. 30, pp. 187-192, 1991.

[38] G. S. M. Asmat, M. M. Kibria, and L. Naher, "Trichodina gulshae sp. n. (Ciliophora: Trichodinidae) from the gangetic mystus, Mystus cavasisus (Hamilton-Buchanan, 1822) (Bagridae) in Chittagong," Pakistan Journal of Biological Sciences, vol. 6, no. 18, pp. 1608-1611, 2003.

[39] B. L. Duncan, "Urceolariid ciliates, including three new species, from cultured Philippine fishes," Transactions of the American Microscopical Society, vol. 96, no. 1, pp. 76-81, 1977. 

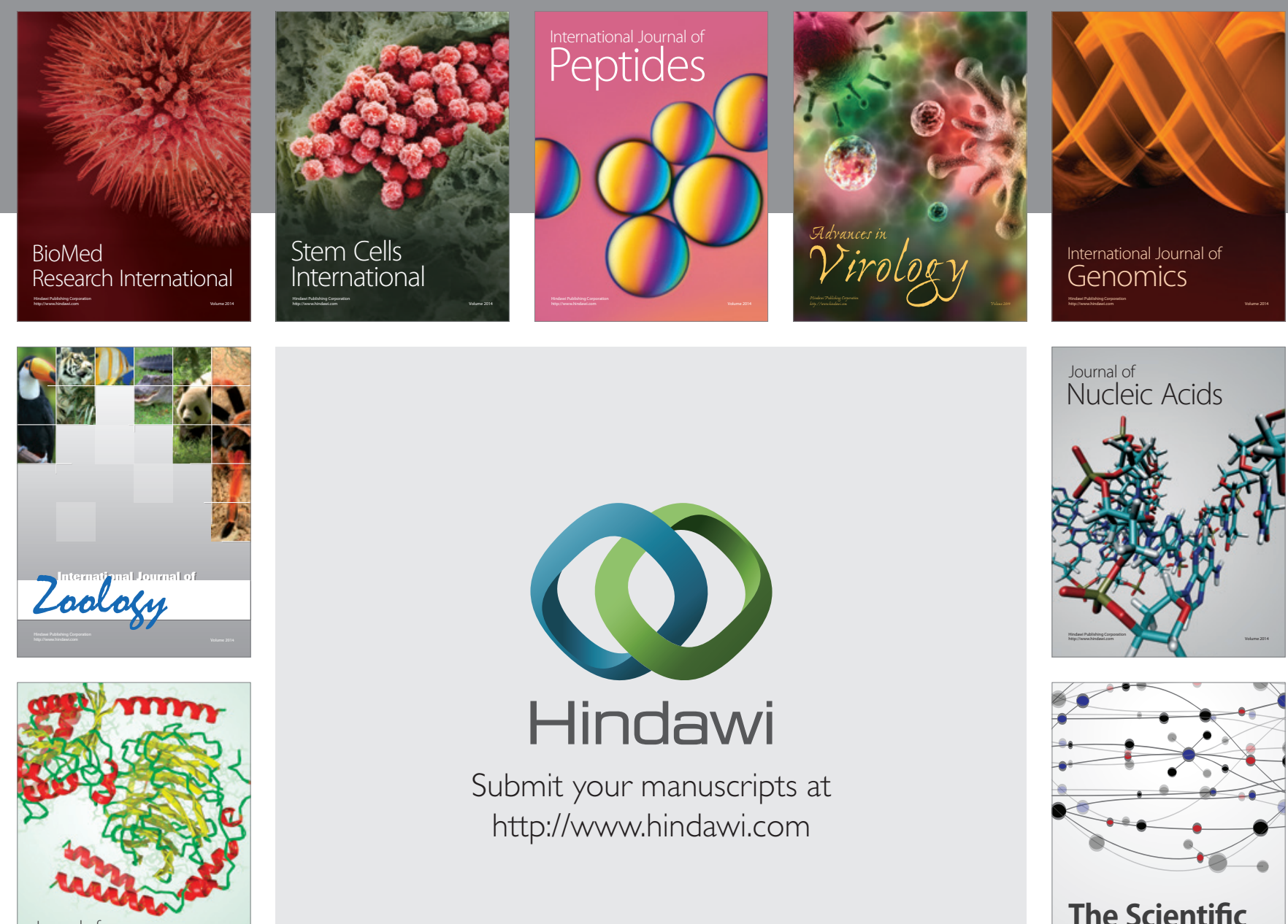

Submit your manuscripts at

http://www.hindawi.com

Journal of
Signal Transduction
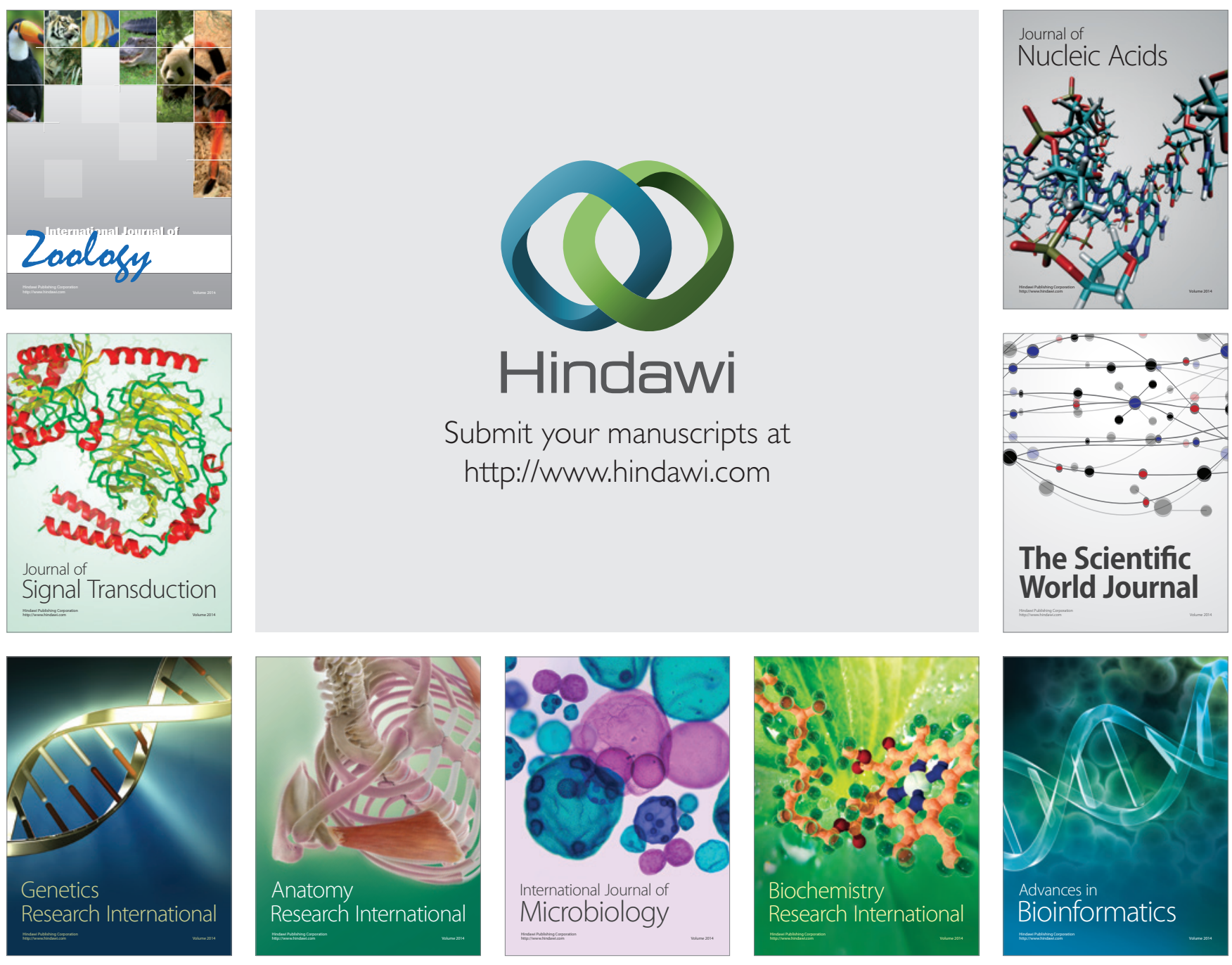

The Scientific World Journal
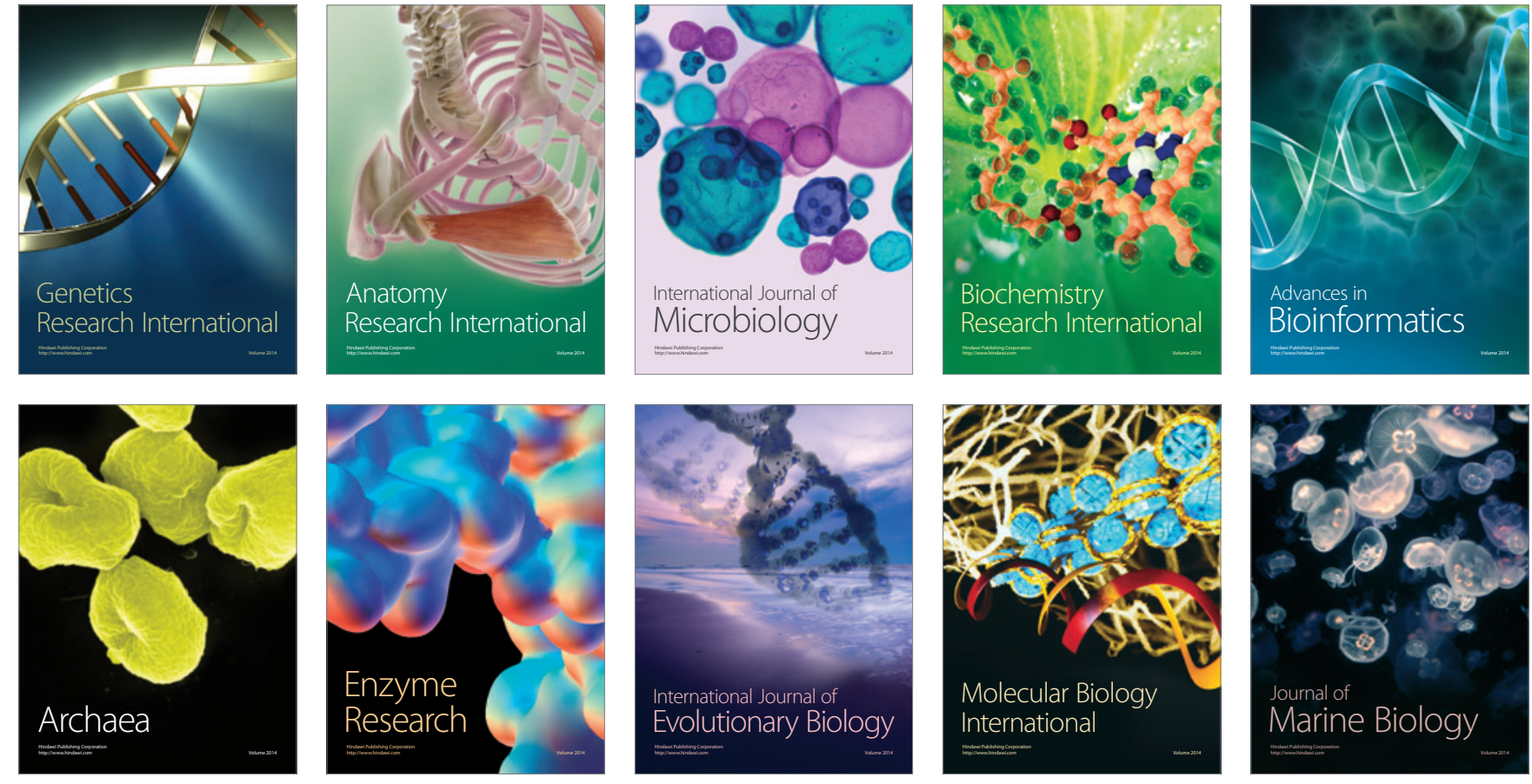